\title{
POMNIK HISTORII PO JAPOŃSKU, CZYLI SYNERGIA POZNAWCZA MIEJSC, KRAJOBRAZÓW, KUNSZTÓW, TRADYCJI I ZWYCZAJÓW
}

Podróż do najbardziej wewnętrznego sedna Japonii ${ }^{1}$

\section{AFFELT Waldemar J. ${ }^{1}$}

${ }^{1}$ Waldemar J. Affelt, Politechnika Gdańska, Uniwersytet Mikołaja Kopernika w Toruniu https://orcid.org/0000-0003-3274-5210

ABSTRAKT: Japońska Agencja ds. Kultury realizuje projekt JAPAN HERITAGE, wynikiem którego będzie sto tematycznych narracji zabytkoznawczych. Wnioskodawcą i beneficjentem jest gmina wiejska lub miejska, ale procedura nominacyjna obejmuje także urząd prefektury. Podkreśla się, iż ta inicjatywa nie konkuruje z Listą Światowego Dziedzictwa UNESCO, ani nie wprowadza nowej kategorii zabytku, wobec czego nie istnieje potrzeba kolejnej zmiany Ustawy z dnia 30 maja 1950 r. o ochronie dóbr kultury. Strategicznie projekt ten służy rewitalizacji społecznej poprzez wzmocnienie poczucia tożsamości oraz intensyfikację krajowego i zagranicznego ruchu turystycznego. Każda narracja JAPAN HERITAGE jest markowym produktem turystycznym, a ilustrujące ją materialne i niematerialne dobra kultury objęte prawną ochroną znajdują się na terenie jednej gminy w kategorii lokalnej lub też w wielu gminach danej prefektury, a nawet kilku prefektur - w kategorii zbiorowej. Istotę tego projektu omówiono na przykładzie narracji nr 019 „Kultura Date zainicjowana przez Masamune”.

SŁOWA KLUCZE: Dziedzictwo Japonii, materialne lub niematerialne dobra kultury, Masamune Date

\section{Wprowadzenie}

Sprawy ochrony zabytków w Japonii reguluje Ustawa nr 214 z 30 maja 1950 roku, znowelizowana ostatnio 30 marca 2007 r. $^{2}$. Ten akt prawny zastąpił poprzednie oraz wprowadził za Konwencją

\footnotetext{
1 Japan Heritage, podtytuł strony, [online]:

https://japan-heritage.bunka.go.jp/en/index.html (dostęp: 30.05.2019).

2 Law for the Protection of Cultural Property of May 30th 1950 [online]:

https://en.unesco.org/sites/default/files/japan_law_protectionproperty_entno.pdf (dostęp: 30.05.2019).
} 


\section{Waldemar J. Affelt}

Haską ${ }^{3}$ pojęcia dobra kulturalnego (ang. cultural property) i kulturalnego dobra niematerialnego. To ostatnie pojęcie początkowo odnoszono do dóbr zagrożonych zniknięciem, ale w aktualizacji z 1954 r. ograniczono ich zakres, dodając wymóg wysokiej wartości artystycznej i historycznej. Aktualizacja Ustawy w 1974 r. wobec szybkiego procesu zmian stylu życia Japończyków rozszerzyła kategorię ludowych dóbr kultury o ich wymiar niematerialny. Chociaż wymagają one dokumentowania, to zaniechano ich ochrony poprzez wpisanie do rejestru zabytków. Ponadto dodano zupełnie nową kategorię dobra, jakim są techniki konserwatorskie i chociaż nie mają one charakteru materialnego (wiedza i umiejętności), to są niezbędne do zachowania obiektów materialnych dla przyszłych pokoleń. Tak więc istota dziedzictwa niematerialnego została rozpoznana w Japonii, a jej nośniki objęte stosowną ochroną na długo przed pojawieniem się konwencji UNESCO ${ }^{4}$.

Interesująco wygląda sprawa szczególnie pięknych scenerii, którą to kategorię wprowadziła Ustawa z 1929 r. ${ }^{5}$ o miejscach historycznych, miejscach malowniczego piękna i pomnikach przyrody. Zrównywała ona ich status ochrony ze świątyniami i chramami, ale również włączała w ten zbiór miejsca, które odwiedzał cesarz (usunięte z listy po 1945 r.). Ta kategoria zabytku szczególnie zaś przywołana wartość estetyczna - znalazła się w Ustawie z 1950 roku, co dzisiaj stanowi istotną różnicę między japońskim a polskim prawem ochrony zabytków.

W 1996 r. wprowadzono nową formę ochrony dóbr kultury poprzez wpisanie na listę tradycyjnych budynków - tzw. registration. Uzupełnia ona istniejący dotąd system ochrony, czyli jej najwyższą formę tzw. designation (narodowe dobro kultury) oraz tzw. selection (prefekturalne dobro kultury) - zapewniając umiarkowane środki ochrony, takie jak zalecenia służb konserwatorskich, powiadomienia, wskazówki, sugestie i porady. Od właścicieli tradycyjnych budynków oczekuje się, aby chronili głównie charakter ich elewacji. W 2004 r. tę formę ochrony rozszerzono na nieruchome materialne dobra kultury ludowej. Również w tym roku uchwalono Ustawę o krajobrazie - pierwszy akt prawa w Japonii stanowiący o odpowiedzialności rządu za zagospodarowanie przestrzenne. W tymże roku wprowadzono nową kategorię dobra kultury Krajobraz Kulturowy, obejmujący takie formacje jak np. tarasy pól ryżowych, czy zagajniki na terenach zabudowanych.

Ustawa z 2008 r. o utrzymaniu i ulepszeniu krajobrazu historycznego przewiduje różne środki ochrony jego charakteru poprzez rozszerzenie wsparcia finansowego i zachęty podatkowe. Omawia również związek między ochroną dóbr kultury a promocją turystyki, czemu już w 2006r. poświęcono ramową ustawę Prawo o narodowej promocji turyzmu $u^{6}$. Wobec dużej dysproporcji w turystycznym ruchu krajowym i zagranicznym oraz wyraźnego przyhamowania procedur

Konwencja o ochronie dóbr kulturalnych w razie konfliktu zbrojnego wraz z regulaminem wykonawczym do tej konwencji oraz protokół o ochronie dóbr kulturalnych w razie konfliktu zbrojnego, podpisane w Hadze dnia 14 maja 1954 roku.

4 Konwencja UNESCO w sprawie ochrony niematerialnego dziedzictwa kulturowego, sporządzona w Paryżu dnia 17 października 2003 r. [online] http://prawo.sejm.gov.pl/isap.nsf/DocDetails.xsp?id=WDU20111721018. (dostęp: 30.05.2019).

5 Historical Sites, Places of Scenic Beauty, and Natural Monuments Preservation Law, 1929.

6 The Tourism National Promotion Basic Law, 2006. 
obejmowania ochroną kolejnych dóbr kultury, wysiłki administracji państwowej i samorządowej zmierzają ku intensyfikacji krajowej turystyki kulturalnej Japończyków. Obecnie system krajowy operuje sześcioma kategoriami zabytków:

- ważne materialne dobra kultury: dzieła sztuk pięknych i rzemiosł;

- ważne niematerialne dobra kultury: sztuki widowiskowe, techniki rzemieślnicze;

- ważne zabytki: miejsca historyczne, miejsca malowniczego piękna, pomniki przyrody;

- ważne materialne dobra kultury ludowej;

- ważne niematerialne dobra kultury ludowej;

- archeologiczne dobra kultury (obiekty podziemne).

Przymiotnik „ważny” oznacza najwyższą państwową i ścisłą formę ochrony, ale ochrona niektórych dóbr może mieć charakter regionalny (prefektura: np. wybrane techniki konserwatorskie; ochrona obszarowa grupy budynków) lub lokalny (gmina: np. budynki), co daje ogółem siedemnaście typów ochrony dóbr kultury. Ponadto Ustawa z 1950 r. wprowadza tytuł Żywego Skarbu Narodowego nadawany mistrzom sztuk i rzemiosł, a także mistrzom tradycyjnego teatru japońskiego (Noh, Bunraku, Kabuki). Głównym tego celem jest ochrona japońskich tradycji oraz zapewnienie ich kontynuacji.

\section{Najnowsza innowacja w japońskim systemie ochrony zabytków}

Przed laty w Agencji ds. Kultury powstał pomysł na Dziedzictwo Japonii, czyli projekt JAPAN HERITAGE. Zwrócono się do gmin z zaproszeniem do uczestnictwa i zgłaszania propozycji. Niestety, do sierpnia 2014 roku napłynęło 38 aplikacji (na ogólną liczbę ponad tysiąca siedmiuset gmin), z czego jedynie kilka spełniało warunki. Tymczasem założono, iż „wartość dodana do wartości dóbr kultury, taka jak powiązanie ich z lokalnymi opowieściami i wprowadzenie systemu ich upowszechnienia, a także wdrożenie zintegrowanego programu rewitalizacji społeczności, związanego z rozwojem przemysłowym, promocją turystyki i zasobów ludzkich wraz z rozwojem społeczności lokalnej (oraz ewentualnie gmin sąsiednich) przyczynią się do uświadomienia i wzmocnienia poczucia tożsamości wśród mieszkańców. Oznacza to także wypromowanie marki miejsca, co ostatecznie doprowadzi do rewitalizacji całego regionu." Projekt inicjuje gmina wiejska lub miejska, a jego opis przekazuje do prefektury. Na szczeblu terenowym jest on dyskutowany, oceniany i ewentualnie zwrócony do uzupełnienia. Ostateczną decyzję podejmuje w Tokio Rada ds. Przeglądu Dziedzictwa Japonii złożona z profesjonalistów spoza Agencji ds. Kultury.

Istotą Dziedzictwa Japonii jest tematyczna opowieść interpretująca wartości i znaczenie wybranych materialnych i niematerialnych dóbr kultury, tworzących zbiór atrakcji turystycznych jednej gminy lub kilku. Narracja powinna posiadać następujące cechy:

- dotyczy unikatowych dawnych tradycji lub zwyczajów lokalnych, które są przekazywane

Outline of "Japan Heritage" Program, Agency for Cultural Affairs, March 2015, para 1, [online]: https:// japan-heritage.bunka.go.jp/en/img/about/Outline\%20of\%20Japan\%20Heritage.pdf (dostęp: 30.05..2019). 
z pokolenia na pokolenie;

- ma jasno określony temat i dotyczy dóbr kultury zachowanych na obszarze gminy, takich jak obiekty budowlane i ruchome, stanowiska archeologiczne, miejsca i krajobrazy malowniczego piękna oraz lokalne festiwale;

- nie jest jedynie podsumowaniem historii regionalnej lub opisem lokalnych dóbr kultury, ale tworzy synergiczną wartość dodaną jako holistyczna całość.

Zaleca się taki sposób komunikowania tych treści, aby były zrozumiałe dla osób nie posiadających specjalistycznego przygotowania. Kryteriami ustanowienia takiej narracji jako Dziedzictwo Japonii są:

- Narracja odnosi się do różnych historycznych cech regionu i może być instrumentem w budowaniu atrakcyjności Japonii jako całości.

- Wnioskodawca ma wizję rozwoju regionu oraz konkretną strategię wykorzystania w tym celu dóbr kultury objętych prawną ochroną.

- Projekt ma na celu rewitalizację lokalnej społeczności oraz skutecznie upowszechnia narrację zabytkoznawczą w kraju i za granicą.

Status Dziedzictwa Japonii obejmuje dwie kategorie: lokalną, gdy narracja odnosi się do jednej gminy, i/lub zbiorową, gdy dotyczy kilku gmin. Każda nominacja musi zawierać co najmniej jedno narodowe - czyli ważne - dobro kultury o najwyższym statusie ochrony.

29 czerwca 2015 r. w Muzeum Narodowym w Tokio odbyło się Pierwsze Forum JAPAN HERITAGE. Minister i wiceminister Edukacji, Kultury, Sportu, Nauki i Techniki wręczyli osiemnaście pierwszych certyfikatów Japońnkiego Dziedzictwa, a następnie odbył się panel dyskusyjny z udziałem komisarza ds. kultury i członka japońskiej Rady ds. Przeglądu Dziedzictwa. Na stoiskach wystawienniczych znajdowały się pierwsze publikacje opatrzone logo JAPAN HERITAGE. Już same tytuły zwycięskich narracji ukazują zróżnicowanie ich tematyki oraz zakresu terytorialnego i charakteru reprezentatywnych dóbr kultury. ${ }^{8}$ Druga krajowa konferencja JAPAN HERITAGE odbyła się w październiku 2018, gdy zaprezentowano już 49 certyfikowanych narracji, a trzecia w maju 2019, wprowadzająca szesnaście kolejnych. ${ }^{9}$ Do roku 2020 planuje się ustanowienie 100 narracji JAPAN HERITAGE. Jest to rok letnich igrzysk olimpijskich w Tokio, w związku z czym przewiduje się przyjazd ponad 20 milionów turystów zagranicznych. Zaplanowano zatem wydanie wielojęzycznych materiałów promujących rodzime dobra kultury objęte narracjami projektu, przy intensywnym wykorzystaniu możliwości elektronicznych technik informacji i komunikacji. Agencja ds. Kultury zapewnia finansowe wsparcie przez pięć lat od ustanowienia danej narracji. Dzięki temu powstają nowe miejsca pracy kwalifikowanej obsługi obiektów dziedzictwa, turystyczna infrastruktura techniczna (parkingi, toalety, miejsca wypoczynku, punkty gastronomiczne, udogodnienia dla niepełnosprawnych itp.) i informacyjna (drogowskazy, panele informacyjne, metalowe trójwymiarowe makiety

Zob. Japan Heritage [online]: https://japan-heritage.bunka.go.jp/en/img/about/nihon_isan_pamphlet_ english.pdf (dostęp: 30.05..2019).

$9 \quad$ Zob. https://japan-heritage.bunka.go.jp/ja/special/sp190606.html. 
danego miejsca dla ociemniałych, kamienne słupy z wyrytą nazwą plenerowego obiektu itp.) oraz wzmocniony zostaje sektor przemysłu pamiątkarskiego.

\section{Narracja nr 019 „Kultura Date zainicjowana przez Masamune”10}

Date Masamune (1567-1636), feudalny władca okresu Walczących Państw (1467-1603), jest powszechnie znaną postacią historyczną, głównie ze swoich osiągnięć politycznych i wojskowych, ale był on także intelektualistą, który założył miasto Sendai w odległym od stolicy regionie Tohoku oraz uczynił z niego centrum kultury promieniujące ku jej tradycyjnym ośrodkom w Nara, Kioto i Edo. ${ }^{11}$

Jego wyjątkowe talenty i wyrafinowany gust zaowocowały „Kulturą Date”, która połączyła lokalną tradycję z modnym i luksusowym blichtrem stołecznej kultury Momoyama, nie stroniąc od wpływów Zachodu, czyli Europy. W rezultacie oryginalna kultura Sendai rozkwitła dzięki wysiłkom Date i została przekazana późniejszym pokoleniom, w tym także do innych regionów Japonii oraz została upowszechniona w całym społeczeństwie od klasy samurajów po zwykłych ludzi.

Narrację Dziedzictwa Japonii o kulturze Date Masamune ilustruje pięćdziesiąt niematerialnych oraz materialnych ruchomych i nieruchomych dóbr kultury znajdujących się $\mathrm{w}$ prefekturze Miyagi w sąsiadujących z sobą miastach Sendai, Tagajo, Shiogama i Matsushima. Pomyślana została jako pewien czasoprzestrzenny system poznawczy, w którym można wyodrębnić pięć stref:

I strefa: Date Masamune i kultura domeny Sendai: ruchome dobra kultury nr 1-4, personalnie związane bezpośrednio z osobą Masamune jako swoiste relikwie - przedmioty, które posiadał i dotykał.

II strefa: Tworzenie Kultury Date przez Masamune: ruchome i nieruchome dobra kultury nr 5-15 powstałe za życia Date i związane z jego aktywnościami.

III strefa: Rozprzestrzenianie się Kultury Date w domenie Masamune po jego śmierci, kontynuowane przez rodowych następców: różnorodne dobra kultury nr 16-23: 3 typy obiektów ruchomych oraz 5 budynków religijnych, do powstania których przyczynili się członkowie klanu Date, w tym kolejni władcy Sendai.

IV strefa: Rozprzestrzenienie Kultury Date w całym kraju: różnorodne dobra kultury nr 24-35: 5 budynków oraz jeden krajobraz i 6 miejsc malowniczego piękna.

V strefa: Rozprzestrzenienie Kultury Date pomiędzy zwykłymi ludźmi: różnorodne dobra kultury nr 36-50: elementy dziedzictwa niematerialnego zawarte w 6 sztukach widowiskowych i 3 festiwalach oraz wiedza i umiejętności niezbędne w 6 rzemiosłach tradycyjnych w prefekturze Miyagi.

10 "DATE Culture" fostered by Masamune, [online]: http://datebunka.jp/en/ (dostęp: 30.05 .2019 r.).

11 Zob. Masamune Date, [online]: https://pl.wikipedia.org/wiki/Masamune_Date (dostęp: 30.05.2019 r.). 
A oto lista owych dóbr kultury (numery dóbr uwzględniono w opisie stref powyżej), tworzących desygnaty opowieści JAPAN HERITAGE nr 019:

1. Pięcioczęściowa czarna lakierowana zbroja oraz hełm ozdobiony złoconym sierpem półksiężyca maetate, używana przez Date Masamune.

2. Wełniany fioletowy płaszcz jinbaori z kręgami w pięciu symbolicznych barwach shinto oraz złoto-haftowanym herbem klanu (dwa wróble w locie w kręgu liści bambusa), będący własnością kolejnych władców domeny Sendai od czasów Date. (Ryc. 1)

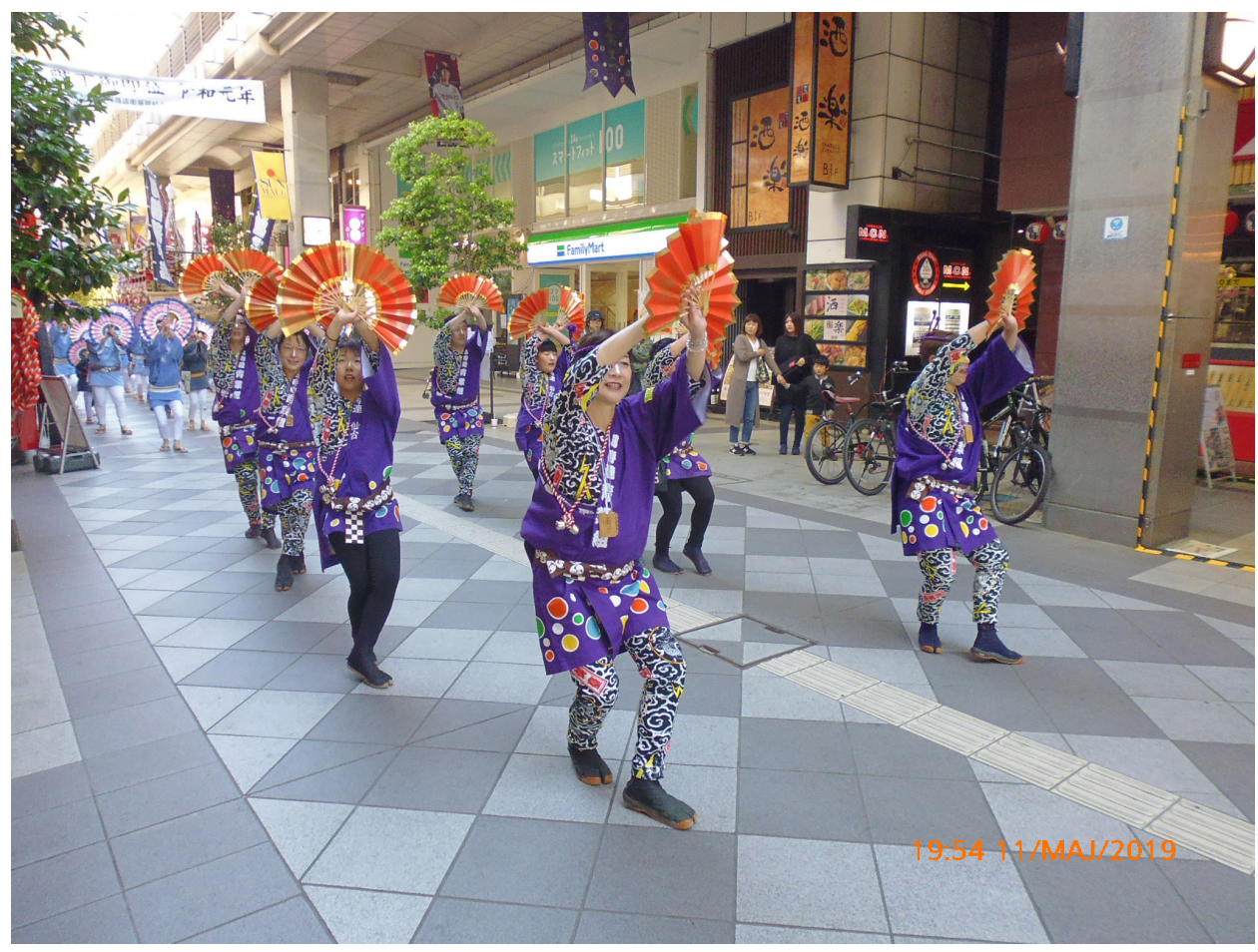

Fot. 1 Sendai, próba występu na tydzień przed festiwalem Aoba Matsuri2019; jinbei grupy wykonującej taniec Suzume-Odori jest zainspirowane fioletowym płaszczem jinbaori Date Masamune (porównaj poz. 2). Fot. W. Affelt

3. Artefakty wydobyte z kaplicy grobowej Mauzoleum Date Zuihoden w Sendai: złota broszka w stylu europejskim (import?), skrzynka na listy zdobiona złotym lakierem.

4. Matsushima, rzeźba naturalnych rozmiarów ukazująca siedzącego Date, powstała w 17. rocznicę śmierci Masamune na zlecenie wdowy po nim - Yotokuin. Umieszczono ją w 1652 r. w świątyni Zuiganji w Matsushimie. Mówi się, że postać DATE została odtworzona na podstawie zapamiętania przez wdowę i uważana jest za najbardziej realistyczną jego podobiznę portretową, ukazującą brak prawego oka, które stracił w dzieciństwie. Badanie obiektu podczas prac konserwatorskich w roku 2012 wykazało, że użyto rzeczywistej zbroi z epoki Walczących Państw Sengoku (1493-1573). (Ryc. 2) 


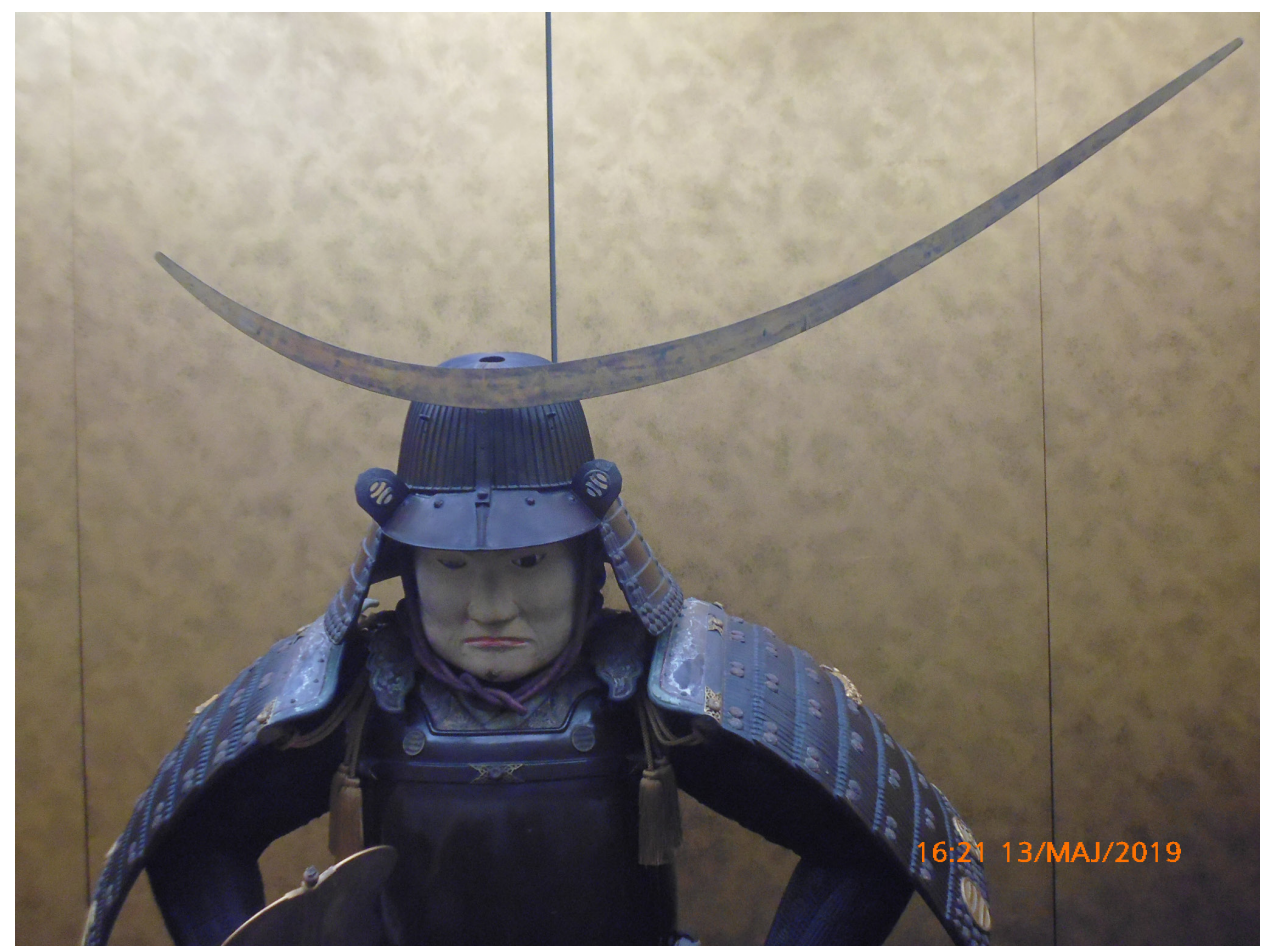

Fot. 2 Matsushima, Muzeum Świątyni Zuiganji, drewniana rzeźba postaci siedzącego w zbroi Date Masamune z 1652 r., przedstawiająca go w hełmie z ulubionym przez niego złoconym półksiężycowym ornamentem maetate. Fot. W. Affelt

5. Miejsce po zamku w Sendai na plateau wzgórza Aoba górującego nad miastem. Jedynie kamienie bazowe filarów dawnej drewnianej konstrukcji wskazują lokalizację głównego budynku honmaru, który został rozebrany w latach 70. XIX w., po zajęciu zamku przez siły rządowe Restauracji Meiji podczas wojny boshin ${ }^{12}$.

6. Seria rysunków w skali 1:100 przedstawiających honmaru i podzamcze ninomaru warowni Aoba w Sendai, a także główne budynki siedziby władców domeny Sendai kamiyashiki w Edo. Jest to jedyny zachowany widok tych elewacji.

7. Malowidło „Feniksy” ze ścianki działowej Wielkiej Sali w honmaru zamku w Sendai, w której Date spożywał posiłki - jest to jedyny zachowany element wyposażenia tego budynku.

8. Trzy składane parawany, które zdobiły wnętrza zamku Wakabayashi, gdzie Masamune spędził ostatnie lata swojego życia po abdykacji. Parawan przedstawiający otwarte wachlarze leżące na ziemi pośród roślin jest wersją malowidła ściennego z zamku Aoba. Dwa pozostałe przedstawiają chryzantemy oraz parę saren siedzącą pośród koniczyny. Malatury wykonano na podkładzie z płatków srebra, a Masamune wykaligrafował na nich swoje wiersze.

9. Matsushima, świątynia Godaido - mały i skromny budynek wzniesiony w 1604 r. staraniem Date w miejscu pierwotnego z IX wieku. Mieści święte wizerunki Królów Pięciu Mądrości. Świątynia

12 Zob. Wojna boshin, [online]: https://pl.wikipedia.org/wiki/Wojna_boshin (dostęp: 30.05 .2019 r.). 
stoi na wysepce połączonej z lądem drewnianym mostem o czerwonych balustradach, którego pokład tworzą rozsunięte na dystans bale. Powiada się, iż to rozwiązanie uniemożliwiało niegdyś przejście kobietom ubranym w kimono. Wnętrze obiektu bywa dostępne dla publiczności tylko raz na 33 lata, a ostatnio w 2006 roku.

10. Chram Osaki Hachimangu zbudowany w latach 1604-1607 staraniem Date, który sprowadził cieśli z Kioto. Budynek jest przykładem eleganckiego stołecznego stylu Azuchi-Momoyama ${ }^{13}$; pod wspólnym dachem krytym cyprysowym gontem znajduje się główne sanktuarium honden i sala modlitewna haiden oddzielone korytarzem ishi-no-ma.

11. Budynek sali modlitewnej Yakushido w świątyni Mutsukokubunji powstał staraniem Date w 1607 r. w miejscu dawnej sali wykładowej. Wewnątrz znajduje się miniaturowy chram Zsushi. Do wykonania tych dzieł Masamune sprowadził stolarzy i rzemieślników z Senshu w Prefekturze Osaka. Jest to drugi w Sendai, obok głównego budynku chramu Osaki Hachimangu, przykład arcydzieła architektury w stylu okresu Momoyama.

12. Matsushima, zespół buddyjskiej świątyni Zuiganji wzniesiony w 1609 r. przez Masamune obejmuje budynek główny hondo, budynek kuchni kapłanów i łączący je korytarz, a także bogatą dekorację ścian działowych 161 malowidłami wykonanymi w różnych technikach, a w części frontowej na podkładzie z płatków złota. Skrzydła drzwiowe i nadproża pokrywają rzeźbione panele. Malowidła wnętrz reprezentacyjnych są kopiami, ale panele poddano purystycznej konserwacji, odsłaniając drewniane podłoże spod kilku warstw polichromii (Ryc. 3). Podczas remontu ukończonego w 2018 r. odkryto wewnątrz ścian nowatorskie w XVII w. antysejsmiczne usztywnienie konstrukcji budynku układem diagonalnych zastrzałów pomiędzy słupami a ryglami.

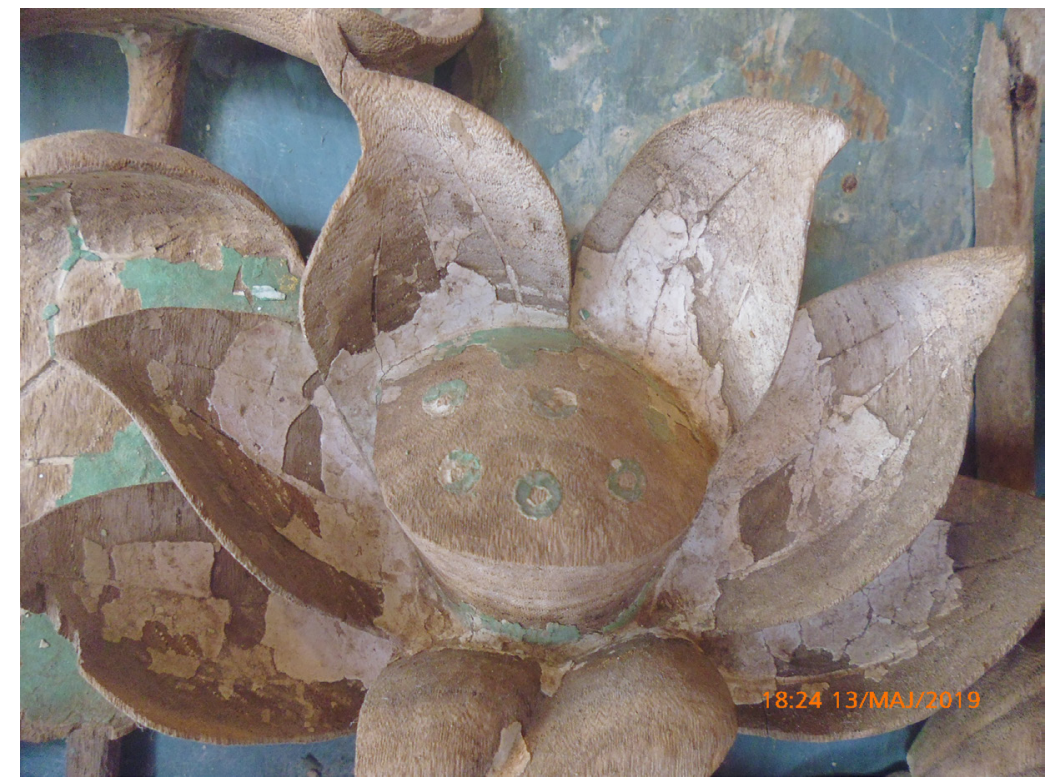

Fot. 3 Matsushima, świątynia Zuiganji, kwiat lotosu - detal snycerski dekoracji drzwi do Sanktuarium po konserwacji. Fot. W. Affelt

${ }^{13}$ Zob. Azuchi-Momoyama [online]: https://pl.wikipedia.org/wiki/Azuchi-Momoyama (dostęp: 30.05.2019 r.). 
13. Przedmioty związane z wyprawą do Europy w okresie Keicho (1596 - 1615), przywiezione z misji, którą Masamune wysłał w 1613 r. do Króla Hiszpanii i Papieża, aby uzyskać zgodę na handel z Meksykiem (Nueva España). Są to: certyfikat obywatelstwa Rzymu wydany dla posła Hasekury Tsunenagi (1571-1622), krucyfiks i portret Tsunenagi wykonany w Europie i ukazujący atrybuty jego nowej religii - chrześcijaństwa. Wyprawa trwała siedem lat, a po powrocie do Sendai zastano zmianę klimatu politycznego, początki prześladowania chrześcijan oraz izolacji Japonii, która miała trwać do końca epoki Edo.

14. Mapa świata Konyo Bankoku Zenzu, której oryginał powstał w Beijin w 1602 r. jako druk z bloków wykonany przez jezuitę Matteo Ricciego. W Japonii zachowały się trzy egzemplarze, a ten przechowywany w kolekcji Biblioteki Prefektury Miyagi w Sendai jest kompletny i zawiera znak producencki Towarzystwa Jezusowego.

15. Manuskrypt Date z życzeniami pomyślności dla miasta „Licząc na trwały dobrobyt Sendai”, napisany w stylu poezji Zen waka, przechowywany w Muzeum Miasta Sendai.

16. Chram Toshogu w Sendai, który założył Tadamune, syn Date, w roku 1654. Obejmuje 5 budynków zdobionych metalowymi złoconymi okuciami. W jego hondo znajduje się miniaturowa kapliczka Zushi bogato zdobiona snycerką malowaną na jaskrawe kolory, zawierająca posąg szuguna Tokugawy Ieyasu (1543-1616). Kamienna brama Torii jest najstarszym tego typu obiektem w prefekturze.

17. Zuihoden, czyli budynek mauzoleum Date oraz mauzolea Kyogamine rodziny Date, które mimo uznania za Skarby Narodowe już w 1902 roku, zostały doszczętnie zniszczone podczas nalotów lotnictwa amerykańskiego w 1945 r. Pierwszy odbudowano w 1979 r., a pozostałe w roku 1985. Podczas rekonstrukcji odkryto artefakty grobowe Masamune: miecz, pudełko na listy i ornamenty, a pomiar jego szczątków pozwolił określić wzrost na $158 \mathrm{~cm}$.

18. Matsushima, mauzoleum Yotokuin zbudowane dla Megohine, wdowy po Masamune, w siódmą rocznicę jej śmierci w 1660 roku przez Tsunamune, wnuka Date. Jest to miejsce modlitwy licznie odwiedzane przez kobiety, szczególnie po 2009 roku, gdy zakończono prace konserwatorskie, w wyniku których budynek dorównał elegancji Mauzoleum Zuihoden.

19. Matsushima, mauzoleum Swiątyni Entsuin jest dedykowane Mitsumune, wnukowi Masamune i zięciowi drugiego władcy Sendai, Tadamune. Zbudowano je w 1647 roku w głębi malowniczego ogrodu tuż obok świątyni Zuiganji. Wewnątrz znajduje się figura konna zmarłego tragicznie Mitsumune w otoczeniu statuetek siedmiu jego wasali, którzy w dowód lojalności swojemu panu oddali życie po jego śmierci. Dekorację budynku stanowią motywy sztuki Zachodu takie jak pik, trefl, karo, serce, róża itp.

20. Shiogama, chram Shiogama-jinja powstał z inicjatywy Tsunamury, czwartego władcy Sendai, w 1695 roku. Prace budowlane zakończył w 1704 roku Yoshimura, piąty władca Sendai. Od zamierzchłych czasów miejsce to cieszyło się szczególną rewerencją dworu cesarskiego oraz lokalnych wielmoży jako siedziba bóstw regionu Tohoku, patronujących żeglarzom, rybakom i ciężarnym kobietom. Także tutaj od stuleci produkuje się sól morską. W tutejszych rytuałach i ceremoniach shinto uczestniczył Masamune, co kontynuowali jego następcy.

21. Kolekcja zbroi należących do kolejnych dwunastu władców domeny Sendai. Przypominają 
one pięcioczęściową konstrukcję używaną przez Masamune, którą cechują trwałość (zaleta na polu walki), łatwość konserwacji oraz estetyka. Większość hełmów jest ozdobiona złoconym półksiężycem, ale w skromniejszych rozmiarach niż na hełmie Masamune.

22. Bambusowe łyżeczki do dozowania sproszkowanej herbaty macha wyrzeźbione przez pięciu kolejnych władców domeny Sendai, poczynając od Masamune. Te utensylia nieodzowne podczas ceremonii herbaty noszą indywidualne cechy nadane im przez właścicieli.

23. Kolekcja trzydziestu pięciu mieczy władców Sendai tradycyjnie ofiarowywanych chramowi Shiogama-jinja na początku sprawowania władzy. Zestaw ceremonialny obejmował trzy miecze dedykowane każdemu z tutejszych trzech bóstw: Betsugu, Sagu i Ugu. Na mieczach wygrawerowano prośby darczyńców oraz umieszczono znaki producenckie płatnerzy.

24. Matsushima, budynek pawilonu herbacianego Kanrantei zbudowano pierwotnie dla zamku Fushimi w Kioto, ale Hideyoshi Toyotomi (1536-1598) $)^{14}$ podarował go Date Masamune. Tadamune, drugi władca Sendai, ponownie obiekt rozebrał i przeniósł w obecne miejsce. Ustawiony na krawędzi niewielkiego półwyspu, otwartym frontem zwrócony ku zatoce, jest dzisiaj publiczną herbaciarnią i jedyną pozostałością po licznej niegdyś zabudowie. Nazwę pawilonu „obserwatorium zmarszczonych wód” nadał Yoshimura, piąty władca Sendai. Ścianki działowe dekorują malowidła pejzażowe na złotym tle. (Ryc. 4)

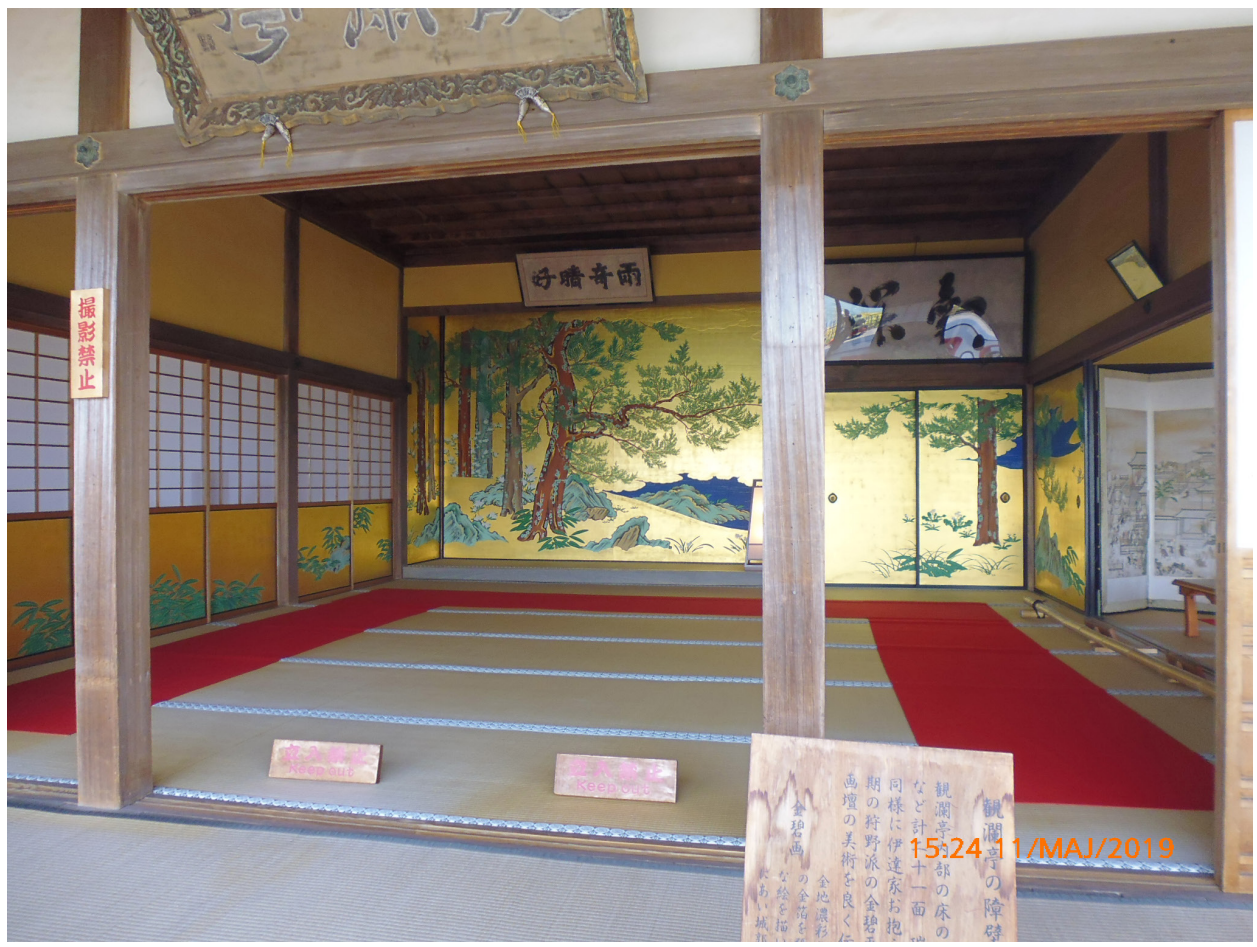

Fot. 4 Matsushima, pawilon herbaciarni Kanrantei, przeniesiony z Kioto przez Tademunę, drugiego władcę Sendai, służący gościom jako willa do obserwacji wód Zatoki oraz księżyca. Fot. W. Affelt

14 Zob. Hideyoshi Toyotomi [online]: https://pl.wikipedia.org/wiki/Hideyoshi_Toyotomi (dostęp: 30.05.2019). 
25. Wzgórze Tsutsujigaoka i sanktuarium Tenjin pośród drzew wiśni płaczącej i dębu są przykładem miejsca malowniczego piękna, pozostającego w stanie niezmienionym przez ponad trzysta lat. Znaleźć tu można kamienne stele z inskrypcjami poezji haiku, nawiązujące do wizyty, jaką złożył Matsuo Basho (1644-1694), podróżujący mnich zen i poeta.

26. Kinoshita i budynek Yakushido wzniósł Masamune w 1607 roku. Ich otoczenie z licznymi kamiennymi stelami z wyrytymi wierszami haiku jest miejscem malowniczego piękna od 2015 roku.

27. Tagajo, miejsce historyczne po zamku Taga z VIII wieku. Badania archeologiczne potwierdziły istnienie na plateau wzgórza nad miastem Tagajo politycznego centrum zarządzania prowincją Matsu na południu regionu Tohoku. Teren zamku był obwarowany wałami ziemnymi i prowadzily do niego dwie przeciwległe bramy. Znaleziono kamienie bazowe drewnianych słupów, których układ pozwolił określić lokalizację i obrys budynków. Opracowano także hipotetyczną stratygrafię rozwoju całego założenia przestrzennego, eksponowaną na miejscu. (Ryc. 5)

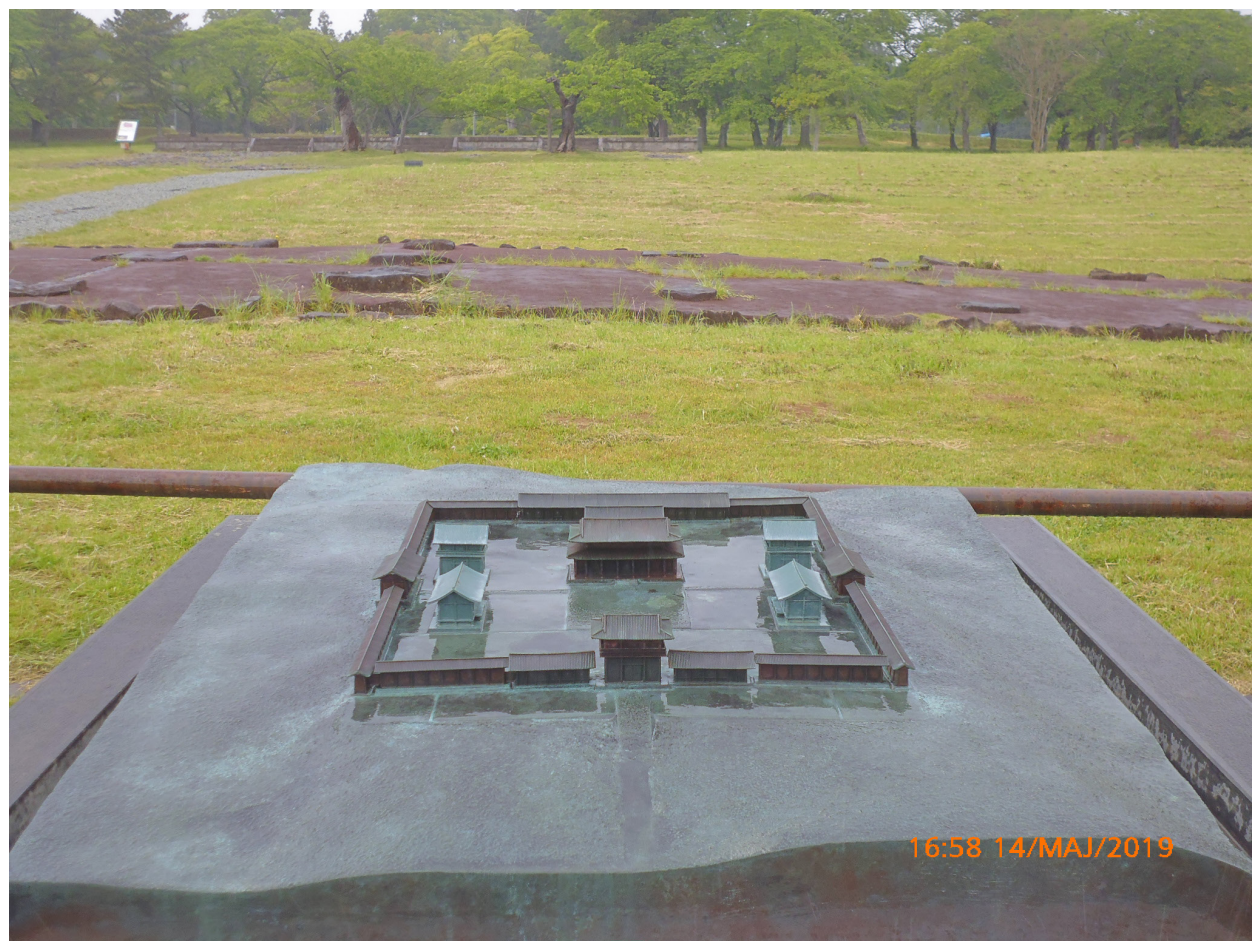

Fot. 5 Tagajo, miejsce zabytkowe po zamku z VIII w. - siedzibie władz ówczesnej prowincji Matsu; na pierwszym planie metalowa makieta ukazująca fazy rozbudowy zespołu, dalej odtworzenie układu kamieni bazowych słupowej konstrukcji bramy, w dali platforma fundamentowa budynku głównego o podobnej aranżacji. Fot. W. Affelt 
28. Tagajo, pomnik Zamku Taga jest kamienną stelą odkrytą w czasach Tadamune, drugiego władcy Sendai. Wyryto na niej opis prac remontowych prowadzonych na zamku w okresie Nara (733-754). Zabytek ten otoczono opieką, a Tsunamura, czwarty władca Sendai, ufundował pawilon zabezpieczający kamienny blok przed wpływami klimatu. Budził on zainteresowanie uczonych, a poeta Basho poświęcił mu wiersz. (Ryc. 6)

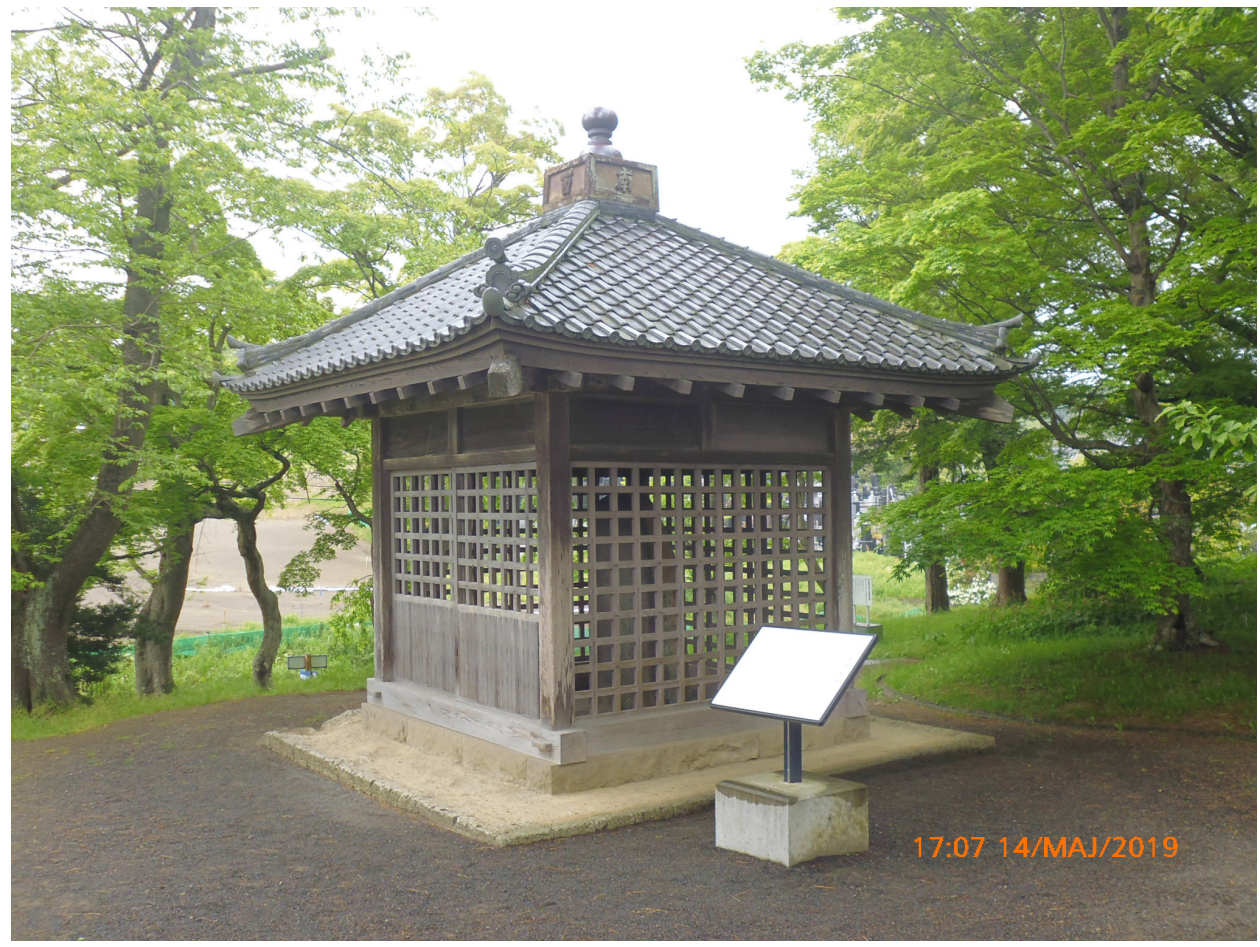

Fot. 6 Tagajo, drewniany pawilon wzniesiony przez Date Tsunamurę (1659-1719), osłaniający zabytkową stelę - pomnik zamku Taga. Fot. W. Affelt

29. Tagajo, Tsubo no Ishibumi jest miejscem malowniczego piękna wokół Pomnika Zamku Taga, z którego otwiera się widok na teren przeciwległej zabudowy zamku z jednej strony oraz na ocean $-\mathrm{z}$ drugiej.

30. Tagajo, wzgórze Suenomatsuyama jest miejscem malowniczego piękna, które inspirowało poetów, pisarzy i malarzy w epoce Edo, znajdujących tu natchnienie. Ograniczone widokiem zmierzwionych sosen na wierzchołku oraz rzędami kamieni nagrobnych u podnóża uważane jest za symbol piękna romantycznego. Dał temu wyraz poeta Basho, konkludując w smutku wizualny kontrast pomiędzy grobami a zwichrowanymi gałęziami drzew.

31. Tagajo, Oki-no-i jest narodowym miejscem malowniczego piękna upowszechnionym przez poetkę Onono Komachi (834-880) i innych. Tsunamura, czwarty władca Sendai, polecił lokalnym przywódcom zapewnienie troski o stan tego zakątka, który dzisiaj jest stawem ze skalną „wysepką”, porośniętą skarłowaciałymi sosenkami, krzewami oraz klonem japońskim acer japonicum. Wokół biegnie jezdnia. 
32. Wysepka Magakigashima w lagunie miasta Shiogama ma zaledwnie 150 metrów średnicy, ale jako miejsce malowniczego piękna od najdawniejszych czasów jest tematem poezji. Np. Matsu Basho w swoim pamiętniku z podróży Oku no Hosomichi opisał scenerie wysepki oglądane w świetle księżyca.

33. Wyspa Oshima w Zatoce Matsushima jest nieregularną w obrysie formacją skalną o stromych zboczach, porośniętą sosnami. ${ }^{15}$ Niezamieszkana, zawiera ślady bytności od pokoleń, gdyż kapłani buddyjscy medytowali tutaj od IX wieku w pustelniach wyciętych w skalnym masywie. To miejsce malowniczego piękna w promieniach wschodzącego z wody słońca uznano za emanację Buddyjskiego Raju - Czystej Krainy. Basho i wielu innych literatów i artystów uwiecznili swoje wrażenia z pobytu na Oshimie. (Ryc. 7)

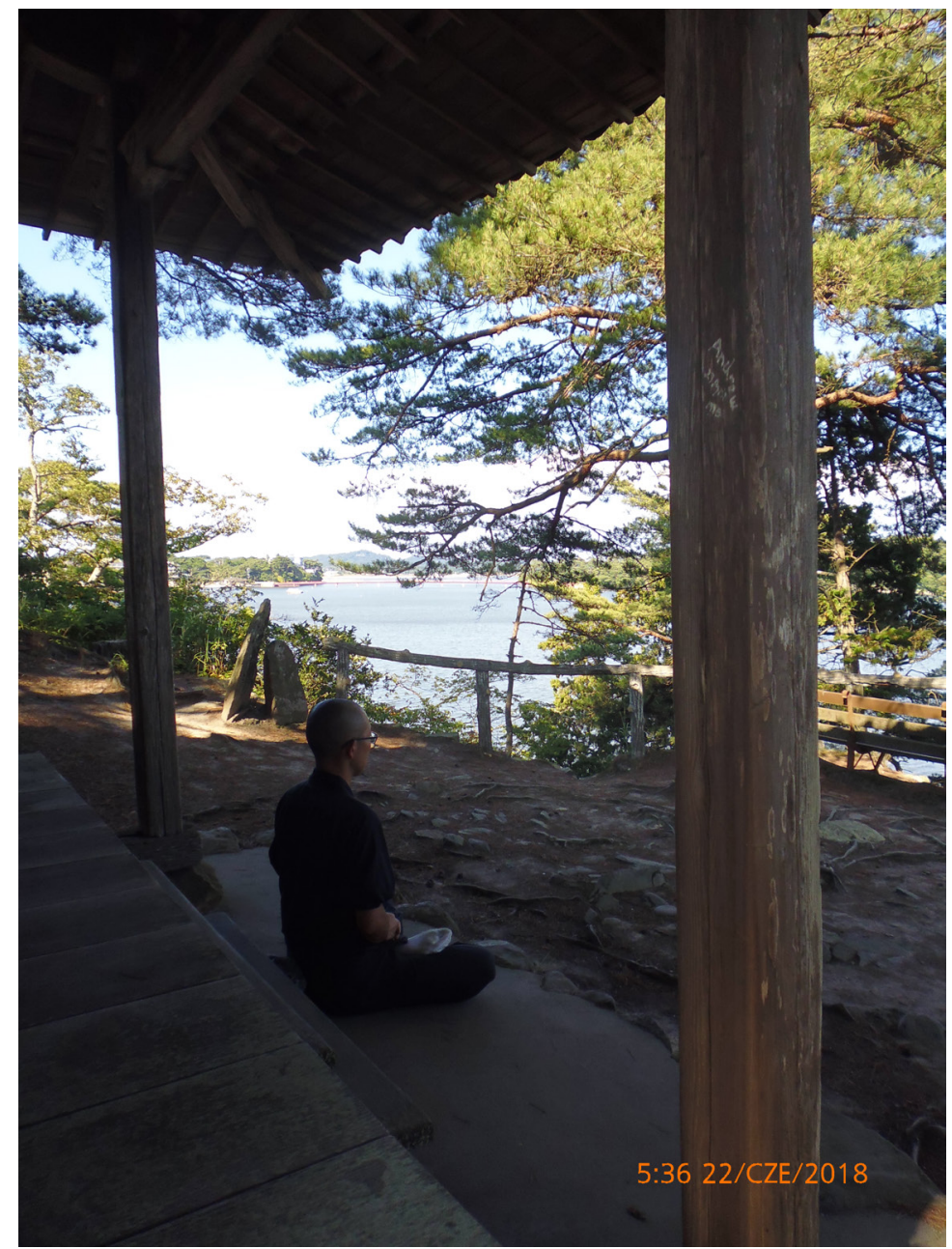

Fot. 7 Wyspa Oshima w Zatoce Matsushima, kapłan buddyjski ze świątni Zuiganji pogrążony w medytacji na przedprożu archaicznego pawilonu. Fot. W. Affelt

15 Zob. Oshima Island na Google Map [online]: https://www.google.com/maps/@38.3644462,141.062592,58m/ data $=! 3 \mathrm{~m} 1 ! 1 \mathrm{e} 3$. 
34. Pejzaż Zatoki Matsushima to jeden z trzech najpiękniejszych krajobrazów Japonii według Hayashi Gahō (1618-1688), neokonfucjonisty i szefa rządowej edukacji. Cała linia brzegowa zatoki oraz 262 wyspy stanowią miejsce - tym razem bardzo rozległe o pow. 9717 hektarów malowniczego piękna. (Ryc. 8)

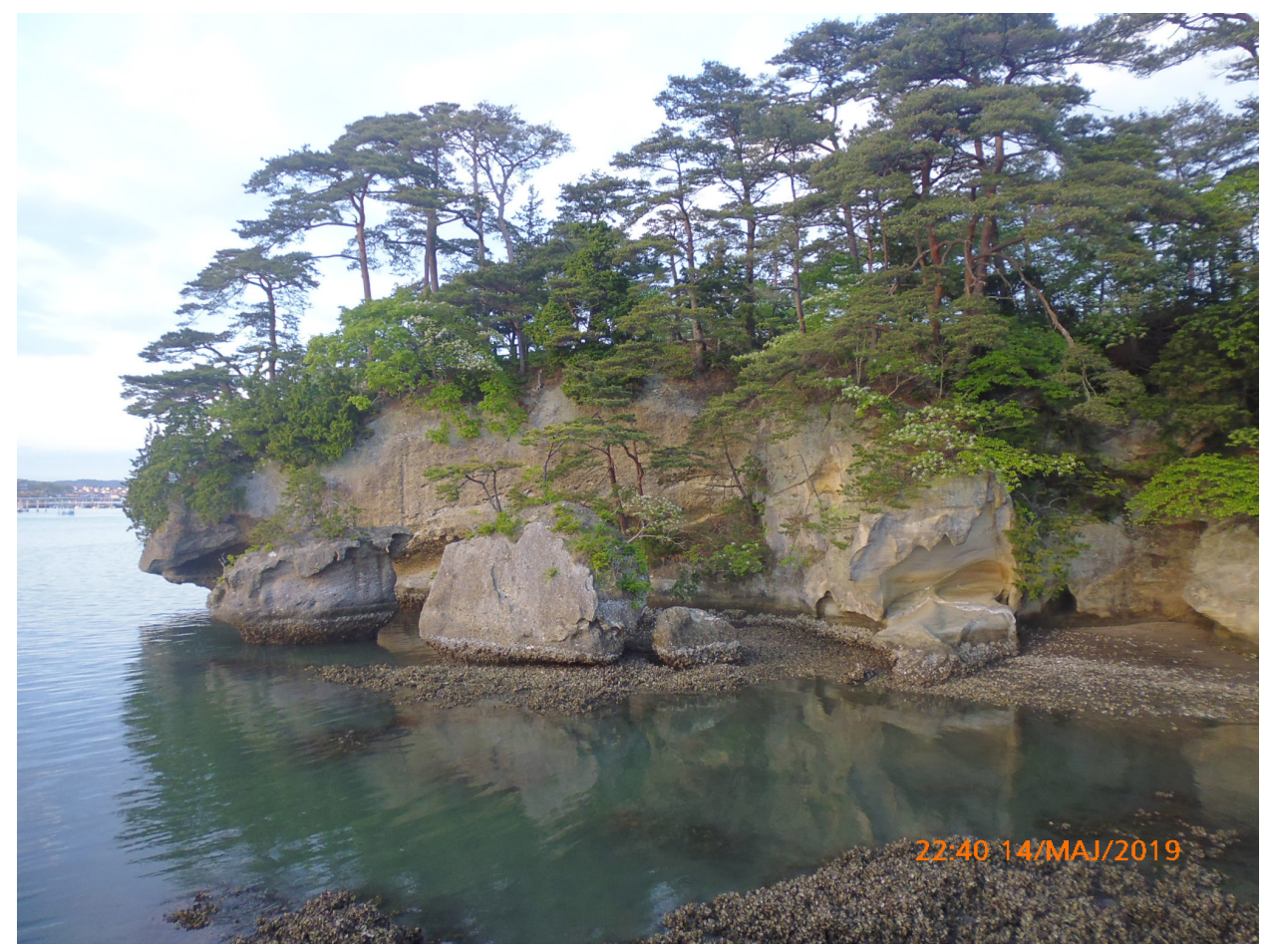

Fot. 8 Wyspa Fukuura na zatoce Matsushima; odpływ odsłania nieregularny obrys skały oraz siedliska ostryg, z których słynie to miejsce. Fot. W. Affelt

35. Matsushima, punkt widokowy Tomiyama ze świątynią Kannondo i dzwonem bonsho, z którego roztacza się jeden z czterech najpiękniejszych widoków na Zatokę. To miejsce malowniczego piękna jest związane z Sakanoueno Tamuramaro (758-811), pierwszym szogunem okresu Heian (794 n.e. - 1185), ale znaczący remont świątyni wykonano na polecenie Irohahime, pierwszej córki Masamune, której imię nosi świątynny dzwon. O miejscu tym pisze Kawai Sora (16491710) w swoim pamiętniku z podróży, jaką odbył wespół z Matsuo Basho.

36. Taniec Noh Kagura wykonywany w świątyni Osaki Hachimangu we wrześniu. Ta starodawna forma przedstawienia muzyczno-wokalnego i tańca istnieje dzięki amatorskim grupom skupionym przy chramach shinto, podtrzymujących to dziedzictwo niematerialne. To $\mathrm{z}$ tej formy widowiska ludowego w XIV wieku wyrósł, a w okresie Edo wysublimował, dworski teatr Noh, przejmując stylistykę kostiumów, melodykę i treści przedstawień.

37. Taniec Akiu no Taue Odori o sadzeniu ryżu kultywowany w mieście Akiu, jest przetrwalnikową formą rytuału shinto wykonywanego od starożytności w regionie Tohoku dla zapewnienia obfitych żniw. W obecnej formie znany od XVII w. i wykonywany przez zespół 8 kobiet i dwóch 
lub czterech mężczyzn z towarzyszeniem fletu, bębnów i dzwonków. Wpisany w 2009 roku na Listę Dziedzictwa Niematerialnego UNESCO, poz. 236.

38. Osawa no Taue Odori jest starodawnym rytualnym tańcem o sadzeniu ryżu wykonywanym corocznie od 1981 roku w gminie Osawa, w sierpniu w chramie Yasaka. Tadamune, drugi władca Sendai, wydał pozwolenie na używanie herbu mon klanu Date „Bambus i wróble” na strojach tancerzy, którymi są damskie kimona santime.

39. Spektakle taneczne Shishiodori i Kenbai z Kawamae są wykonywane w lipcu w miejscu łowienia ryb preferowanym przez Masamune w górnym biegu rzeki Hirose. Yoshimura, piąty władca Sendai, ustanowił tę tradycję w wyniku przeglądu wszystkich form teatru ludowego w swojej domenie, uznając te przedstawienia za szczególnie eleganckie. Wykonawcy uzyskali prawo używania jedwabnych kurtyn oraz emblematu Kuyo-mon na kostiumach - okrąg otoczony przez 8 mniejszych kręgów.

40. Spektakle taneczne Shishiodori i Kenbai z Fukuoki zostały przeniesione do Sendai z sąsiadującej od północy prefektury Iwate w 1648 roku - pierwszy, a w kilka lat później - drugi, za pośrednictwem świątyni Ryuhoji. Shishiodori pochodzi ze starożytnych Indii i opowiada o głodzie spowodowanym przez owady - szkodniki ryżowe, któremu zaradziły dziesiątki tysięcy jeleni. Stąd elementem kostiumu jest rogata maska. Natomiast Kenbai - taniec diabelskiego miecza - wymaga maski demona. Oba tańce wykonuje ośmiu mężczyzn.

41. Festiwal Matsutaki (Donto-sai Festival) odbywa się corocznie w chramie Osaki Hachimangu 14 stycznia po zachodzie słońca i trwa do świtania. Uczestnicy modlą się o zdrowie, pomyślność i dobrobyt swoich rodzin w nowym roku, a dekoracje noworoczne oraz amulety z poprzedniego roku zostają spalone w wielkim ognisku na dziedzińcu, które otaczają mężczyźni ubrani jedynie w białe szorty. Uroczystość nosi nazwę hadakamairi - „odwiedzić chram nago”, a jej opis pojawił się ok. 1850 roku w kalendarzu imprez w Sendai.

42. Festiwal Tanabata ${ }^{16}$ jest oparty na chińskiej legendzie Kikkoten o dwóch gwiazdach Kengyu i Shokujo. W Sendai od czasów Edo panuje zwyczaj dekorowania frontów domów kompozycjami z liści bambusa. Po okresie Meji, zaczęto eksponować całe bambusowe gałęzie dekorowane oprócz tradycyjnymi papierowymi paskami modlitewnymi z zapisanymi prośbami, także papierowymi ubrankami i sakiewkami na pieniądze. Festiwal odbywa się od 6 do 8 sierpnia każdego roku i gromadzi tłumy ubranych w kimona i jukaty widzów, w tym wiele młodzieży. (Ryc. 9)

16 Zob. Tanabata [online] https://pl.wikipedia.org/wiki/Tanabata (dostęp: 30.05.2019 r.). 


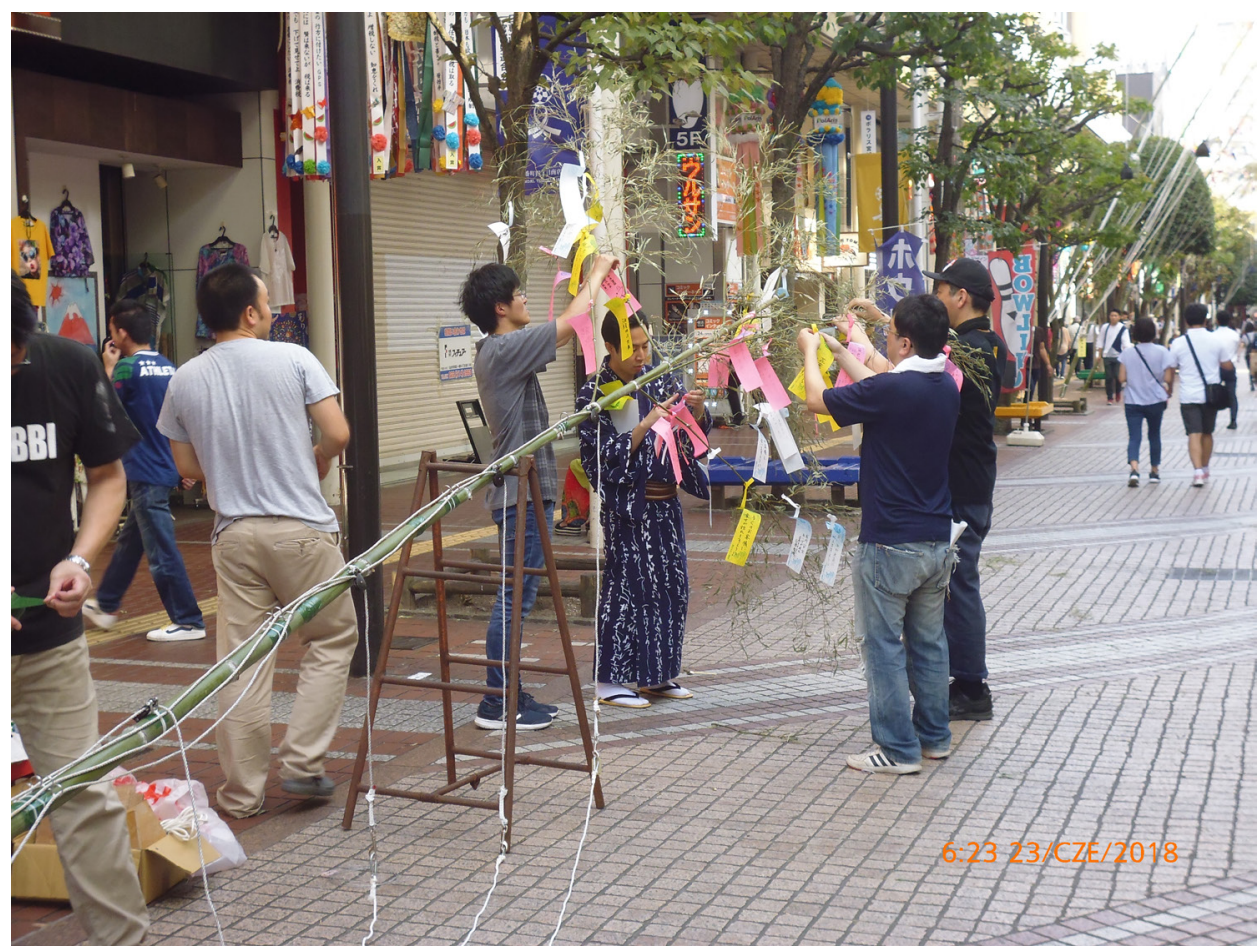

Fot. 9 Sendai, przygotowania dekoracji festiwalu Tanabata; mocowanie do wierzchołka gałęzi bambusowej kolorowych pasków papieru z wypisanymi życzeniami. Fot. W. Affelt

43. Shiogama, rytuały chramu Shiogama-jinja: festiwal Hote-matsuri odbywa się 10 marca od 1682 roku dla ochrony przed siłami zła i ogniem, a festiwal Hana-matsuri w czwartą niedzielę kwietnia od 1778 roku w intencji pomyślnych plonów i ochrony przed suszą. Oba rytuały mają związek z rdzennym ludem Ujiko. Główną atrakcją jest procesja przenośnego sanktuarium mikoshi, ważącego ponad tonę i niesionego przez ubranych na biało 16 mężczyzn, gdzie najtrudniejszy odcinek stanowi pokonanie 202 stopni stromych świątynnych schodów. Festiwal Hana odbywa się podczas kwitnienia wiśni, co jest pretekstem do hanami - oglądania okwieconych drzew i kontemplowania ich uroku. (Ryc. 10)

44. Festiwal Aoba w Sendai jest popularną formą rytuału chramu Aoba-jinja, poświęconego Masamune i kultywowanego w obecnej postaci w trzecią sobotę i niedzielę maja od roku 1985 350. rocznicy śmierci założyciela Sendai. Główną atrakcją jest parada kilkudziesięciu yamaboko - bogato dekorowanych platform na kołach sponsorowanych przez instytucje i korporacje, ciągnionych przez mężczyzn po głównych ulicach miasta. Pomiędzy nimi kilka tysięcy osób w różnym wieku wykonuje Suzume-Odori - taniec wróbli, naśladujący ptasie podfruwania i wirowania, zainicjowany na początku XVII wieku przez budowniczych zamku Aoba. Imprezę otwiera procesja ubranych na biało członków klanu Date z kapłanami shinto, a uświetnia parada mężczyzn w historycznych kostiumach samurajów z postacią Date Masamune w otoczeniu wasali. (Ryc. 11) 


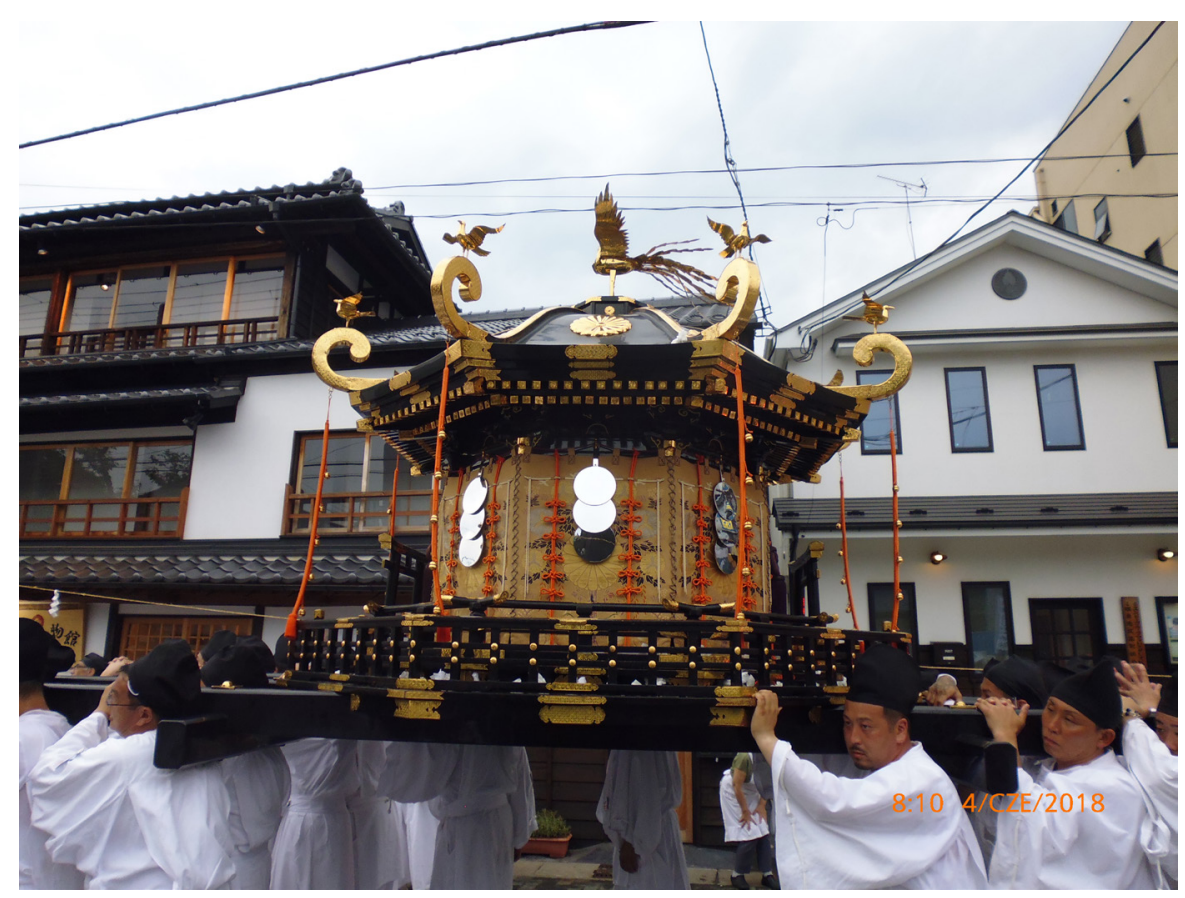

Fot. 10 Shiogama, procesja po mieście z przenośną kapliczką mikoshi podczas dorocznego festiwalu Minato Matsuri w 2018 r. Fot. W. Affelt

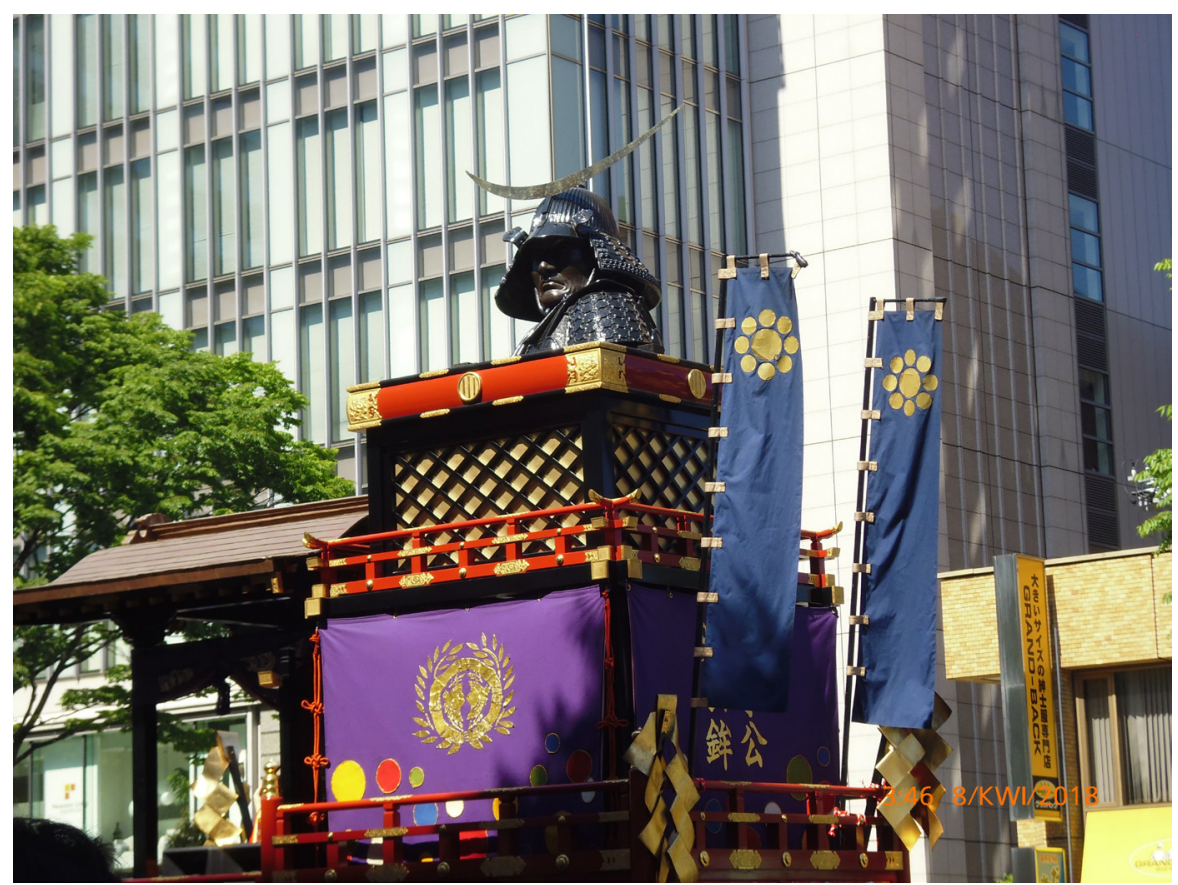

Fot. 11 Sendai, platforma festiwalowa na Aoba Matsuri 2018; ruchoma podobizna Date Masamune unosi się i pozdrawia widzów przy dźwięku fanfar; poniżej na fioletowym tle widnieje mon rodu Date „Dwa wróble i bambus”, a na błękitnych proporcach Kuyo-mon symbolizujący 9 planet buddyjskiej kosmologii, mających wpływ na przyrodę i los człowieka. Fot. W. Affelt 
45. Pędzle pisarskie ofude, które zaprojektował Masamune w 1614 r. przy pomocy mistrzów sprowadzonych z Osaki. Reprezentacyjny pędzel Hagi Fude miał trzonek wykonany z dolnej zdrewniałej części pędu lokalnie uprawianego kwitnącego krzewu Miyaginohagi (Lespedeza thunbergii). W okresie Meiji (1868-1912) bardzo popularny stał się Goshiki Fude - zestaw pięciu pędzli z trzonkami wykonanymi złodygi koniczyny, drewna sosny, japońskiej trawy pampasowej, trzciny i kłączy rdestu.

46. Ceramika tsutsumi początkowo nosiła nazwę „Sugiyama”, ale gdy rozwój Sendai w okresie Genroku (1688-1704) spowodował wzrost popytu na czarki do ceremonii herbaty, garncarze zaczęli budować piece w zalesionej okolicy Tsutsumi-machi, stąd nazwa tutejszych produktów. Styl dekoracji nakrapianym czarnym i białym szkliwem nazwano namako, gdyż przypomina skórę strzykwy. Obecnie istnieje tylko jedna wytwórnia Tsutsumiyaki Kenba Kiln otwarta dla zwiedzających.

47. Ceramiczne lalki tsutsumi z białej po wypaleniu gliny, jaskrawo malowane w stylu ukiyo-e z przewagą czerwieni, których produkcję rozpoczęto w okresie Genroku (1688-1704), dzięki zaproszeniu mistrza Mannemona Kamimury z Edo przez Tsunamurę (1659-1719), czwartego władcę Sendai. Szczyt popularności przypadł w okresie Bunka-Bunsei (1804-1830), a obecnie trzynaste pokolenie ceramików wytwarza te bibeloty przedstawiające słynnych aktorów kabuki, zawodników sumo, czy VIP-ów, ale także realizuje zamówienia na figurki upominkowe lub dziękczynne ofiarowane do chramów, czy amulety pomyślności.

48. Tkanina jedwabna hira, której produkcję rozwinięto w Sendai w połowie okresu Edo. Szyto z niej luksusowe spodnie hakama dla aktorów kabuki, zapaśników sumo, albo używano do produkcji wyrobów kaletniczych. Sztywną, ale elastyczną tkaninę uzyskuje się dzięki zastosowaniu surowej tj. jedynie rozwiniętej, ale nierozciągniętej nici jedwabnej, zwilżonej i silnie uderzanej podczas tkania zarówno wątku jak i osnowy. Właściciele Sendaihira \& Co. Ltd - ojciec i syn Kodo, umiejący produkować hirę zostali uznani w 2002 r. za Żywe Skarby Narodowe.

49. Wyroby hariko z papier-mâché - techniki wynalezionej w okresie Tenpo (1830-1844) przez samuraja Matsukawę Toyonoshina, wasala klanu Date. Typowym wyrobem jest owalna lalka Daruma - wańka-wstańka na podobiznę mnicha Dharmy i pierwszego patriarchy Zen, z twarzą w kolorze indygo i malunkami na ciele przedstawiającymi okręt skarbów albo bóstwa szczęścia. Jest to typowa pamiątka z Sendai, a zarazem amulet przynoszący szczęście. (Ryc. 12)

50. Komody z szufladami tansu rozpoczęto produkować w Sendai pod koniec okresu Edo, a forma współczesnego mebla powstała w okresie Meiji i Taisho. Surowcem jest drewno zelkova, czyli brzostownicy japońskiej, a mebel zostaje wykończony naturalnym lakierem bezbarwnym podkreślającym rysunek usłojenia. Metaloplastyczne okucia z motywem kwiatu piwonii lub głowy chińskiego lwa są wykonywane ręcznie. W 2015 roku umiejętność produkcji tansu uznano za Narodowe Rzemiosło Tradycyjne jako element dziedzictwa niematerialnego. 


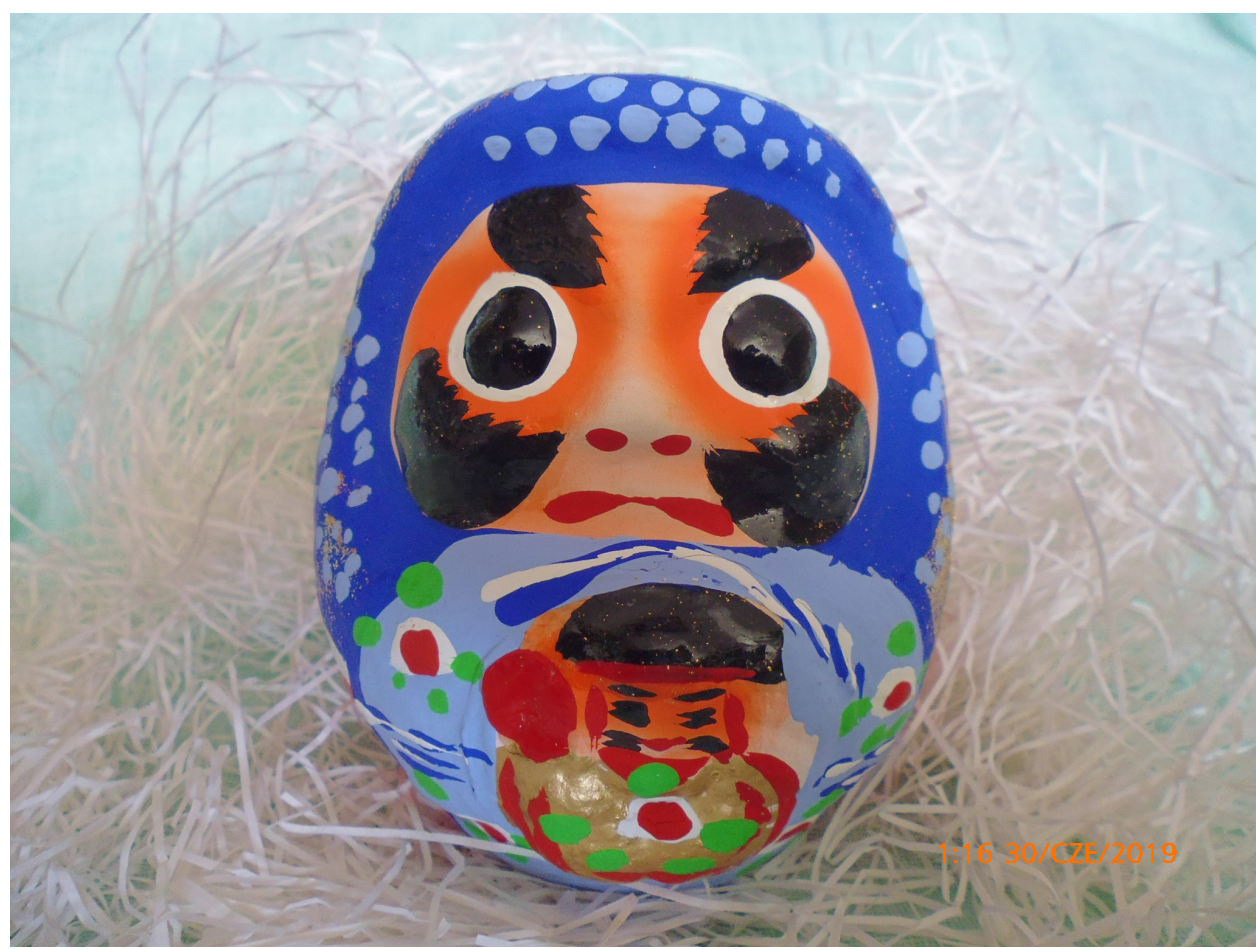

Fot. 12 Błękitna figurka brodatego Darumy z masy papierowej o krzaczastych brwiach i wielkich oczach wszystkowidzących to typowa pamiątka z Sendai - amulet stojący na straży pomyślności całej rodziny i domostwa. Fot. W. Affelt

Pięćdziesiąt tak różnych obiektów dziedzictwa kulturalnego i naturalnego połączone jedną narracją o postaci historycznej Masamune Date i jego osiągnieciach, kultywacji tradycji przez następców i dzisiejszych rezultatach - czyż nie jest to przykład Pięknej Harmonii... Wszak od 1 maja 2019 roku w Cesarstwie Japonii trwa era Reiwa ${ }^{17}$. Z pewnością jest to swoiście japoński Pomnik Historii.

\section{Podsumowanie}

Wspólną cechą japońskiego i polskiego systemu ochrony zabytków jest zastosowanie tych samych nazw podstawowych wartości charakteryzujących zabytek, tj. wartość artystyczna, historyczna i naukowa. Ale w Polsce brak uznania dla osób posiadających szczególne umiejętności czyniące je Żywym Skarbem Narodowym oraz dla miejsc malowniczej scenerii, których naczelnym walorem jest ich wyjątkowa wartość estetyczna.

17 Premier rządu Japonii Shinzō Abe poinformował 2 kwietnia 2019 roku, że oficjalne tłumaczenie nazwy nowej ery Reiwa w języku angielskim to: „Beautiful Harmony”, czyli Piękna Harmonia. Inspiracją po raz pierwszy nie jest tekst chiński, ale japoński wzięty z ośmiowiecznego zbioru poezji waka Man'yōshū, czyli „Kolekcja dziesięciu tysięcy liści”. 
W japońskiej Agencji ds. Kultury znaleziono sposób na połączenie różnych kategorii dóbr kultury - materialnych i niematerialnych, ruchomych i nieruchomych, miejsc i krajobrazów, ludzi i rzeczy, dóbr naziemnych i podziemnych, zabytków najdawniejszych i współczesnych wyrobów rzemiosł artystycznych - poprzez jedną tematyczną narrację interpretacyjną. Można przypuścić, iż podobny koncept przyniósł sukces japońskiej dyplomacji kulturalnej, która doprowadziła do umieszczenia na Liście Światowego Dziedzictwa UNESCO w 2015 r. wpisu seryjnego pod nazwą „Sites of Japan’s Meiji Industrial Revolution: Iron and Steel, Shipbuilding and Coal Mining" obejmującego 23 miejsca w 11 lokalizacjach na terenie ośmiu prefektur. W roku 2018 umieszczono kolejny wpis seryjny „Hidden Christian Sites in the Nagasaki Region”, który objął 12 miejsc na terenie dwóch prefektur.

Opowieści JAPAN HERITAGE są „mapą drogową” po bezkresnej otchłani dziedzictwa przeszłości, prowadzącą od obiektu do obiektu, od wrażenia do przeżycia, od poznawania małych przedmiotów do kontemplacji pięknych widoków i zachwytu wyjątkowymi krajobrazami. Tym sposobem widz może dotrzeć do najgłębszej istoty Japonii, szczególnie gdy podejmie wysiłek samodzielnego już zgłębiania pozyskanych informacji i docierania do źródeł kultury, jej archetypów, mitów, eposów, poezji, rytuałów, teatru, ikonografii, historycznych postaci i wydarzeń. Tak rozumiane Dziedzictwo Japonii nie jest przewodnikiem, czy „spacerownikiem” po zabytkach, ale staje się zaproszeniem do zgłębiania kultury i poznawania jej dóbr jako wiecznie żywego tworu człowieka, kultywowanego, ale i chronionego dla następnych pokoleń. JAPAN HERITAGE zaszczepia Japończykom instynkt poznawczy, a raz rozpoczęta podróż po splątanych wielokulturowych kłączach dynamicznego dziedzictwa może nie mieć końca, prowadząc do innych kultur - jak w przypadku omówionej narracji „Kultura Date” wiodącej do Indii, Chin, Filipin, Meksyku, Hiszpanii i Watykanu - i z powrotem do czasów współczesnych, ale przecież zakorzenionych $\mathrm{w}$ dawności.

Stan prawny ochrony zabytków w Polsce nie zawiera propozycji równie komplementarnego przedmiotu ochrony, jaki oferuje JAPAN HERITAGE. Przykład szczegółowo omówiony w niniejszym artykule wprawdzie pokazuje istotę tego nowatorskiego systemu interpretacji zasobów dziedzictwa, ale nie ukazuje jego wielkiej różnorodności i złożoności także w aspekcie politycznym tzw. prawdy historycznej, co ujawniają pozostałe narracje. System ten rodził się wiele lat, nim jego pierwsze efekty zostały obwieszczone w roku 2015. Jest to nowość w administrowaniu państwem, gdyż prawo inicjatywy przyznano społeczności lokalnej, czyli oddolnemu aktywizmowi typu bottom-up. Jest $\mathrm{w}$ tym pewna analogia do polskiej koncepcji parku kulturowego, jednakowoż brakuje w naszym systemie wyraźnie wyartykułowanej idei holizmu kulturalnego, w którym pod jednym parasolem narracji zabytkoznawczej mieściłyby się jednocześnie wszystkie fenomeny przeszłości, zarówno materialne jak i niematerialne, ruchome i nieruchome, zespoły obiektów budowlanych i kolekcje, widoki, panoramy i krajobrazy, dawność i teraźniejszość. Krajowa lista niematerialnego dziedzictwa kulturowego obejmuje już 37 elementów ${ }^{18}$. Jest to dobry kapitał założycielski do łączenia ich z miejscami, obiektami ruchomymi

18 Krajowa lista niematerialnego dziedzictwa kulturowego [online] http://niematerialne.nid.pl/Dziedzictwo_ niematerialne/Krajowa_inwentaryzacja/Krajowa_lista_NDK/ (dostęp: 20.10.2019). 
i nieruchomymi oraz tworzenia na tej bazie szerokich narracji kulturoznawczych, więc potrzeba jedynie pierwszej jaskółki, która zapowie wiosnę polskiego dziedzictwa i poprowadzi nas ku jego prawdziwie nowoczesnej eksploracji...

W Japonii rozmaite dobra kultury spojono wspólną narracją, która z założenia nie może być „ilustrowaną historią” czy „sumą opisów zabytkoznawczych”. Czym zatem jest JAPAN HERITAGE?

Dziedzictwo Japonii jest markowym produktem intelektualnym, wytworem przemysłu kreatywnego, innowacyjną koncepcją heritologiczną, odpowiadającą potrzebom współczesnego człowieka, wykorzystującą ofertę techniki informacji i komunikacji do poznawania i prezentacji dóbr kultury.

Prefekturalne urzędy konserwatorskie w Japonii na ogół podlegają departamentom edukacyjnym i to do nich napływają wnioski od lokalnych miejskich inspektorów ds. dziedzictwa, ale tylko najlepiej przygotowane znajdują ich zainteresowanie i poparcie $\mathrm{w}$ dalszym procedowaniu. Notabene, omówioną „Kulturę Date” uważam za przykład wzorcowy, ale trudno obcokrajowcowi ocenić dwa kolejne kryteria ewaluacji wniosku: strategiczną koncepcję zarządzania zasobem dziedzictwa i jego otoczeniem oraz wizję związanej z tym rewitalizacji społecznej oraz systemu promocji miejsca dla rozwoju turyzmu.
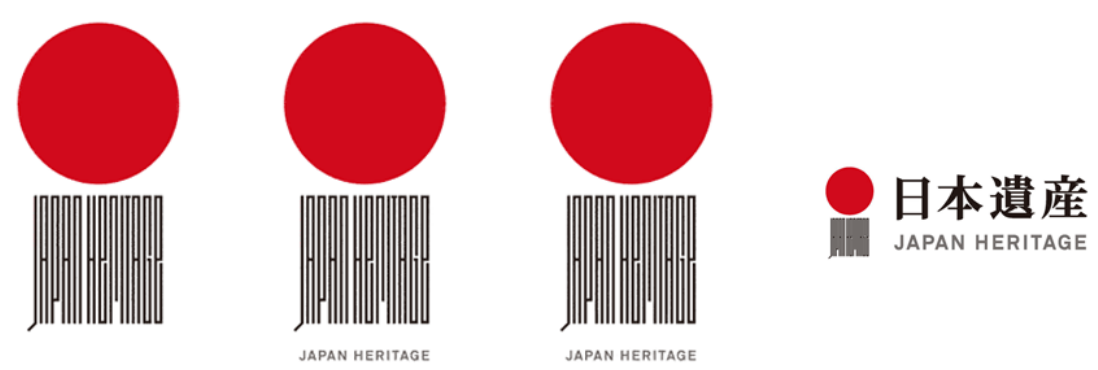

日本遺産

Ryc. 1 Logo JAPAN HERITAGE zostało zaprojektowane w 2015 roku przez artystę grafika użytkowego Taku Sato (ur. 1955, Tokio). Czerwony okrąg symbolizuje Japonię, a grupa cienkich linii tworzy nazwę Japan Heritage. Znak ten wyraża zmianę podejścia do narracji zabytkoznawczej o dobrach kultury poprzez ich usieciowienie współtworzące japońskie dziedzictwo. Fot. W. Affelt

Projekt JAPAN HERITAGE zostanie oceniony po pięciu latach funkcjonowania, czyli po $2025 \mathrm{r}$. Może warto na te raporty poczekać, przed ewentualną inicjacją polskiego odpowiednika, czyli wielodyscyplinarnego i holistycznego projektu kulturalnego i społeczno-ekonomicznego pod nazwą POLSKIE DZIEDZICTWO, który mógłby stać się trwałym rezultatem tegorocznych obchodów 100. rocznicy nawiązania stosunków dyplomatycznych między Polską i Japonią. 


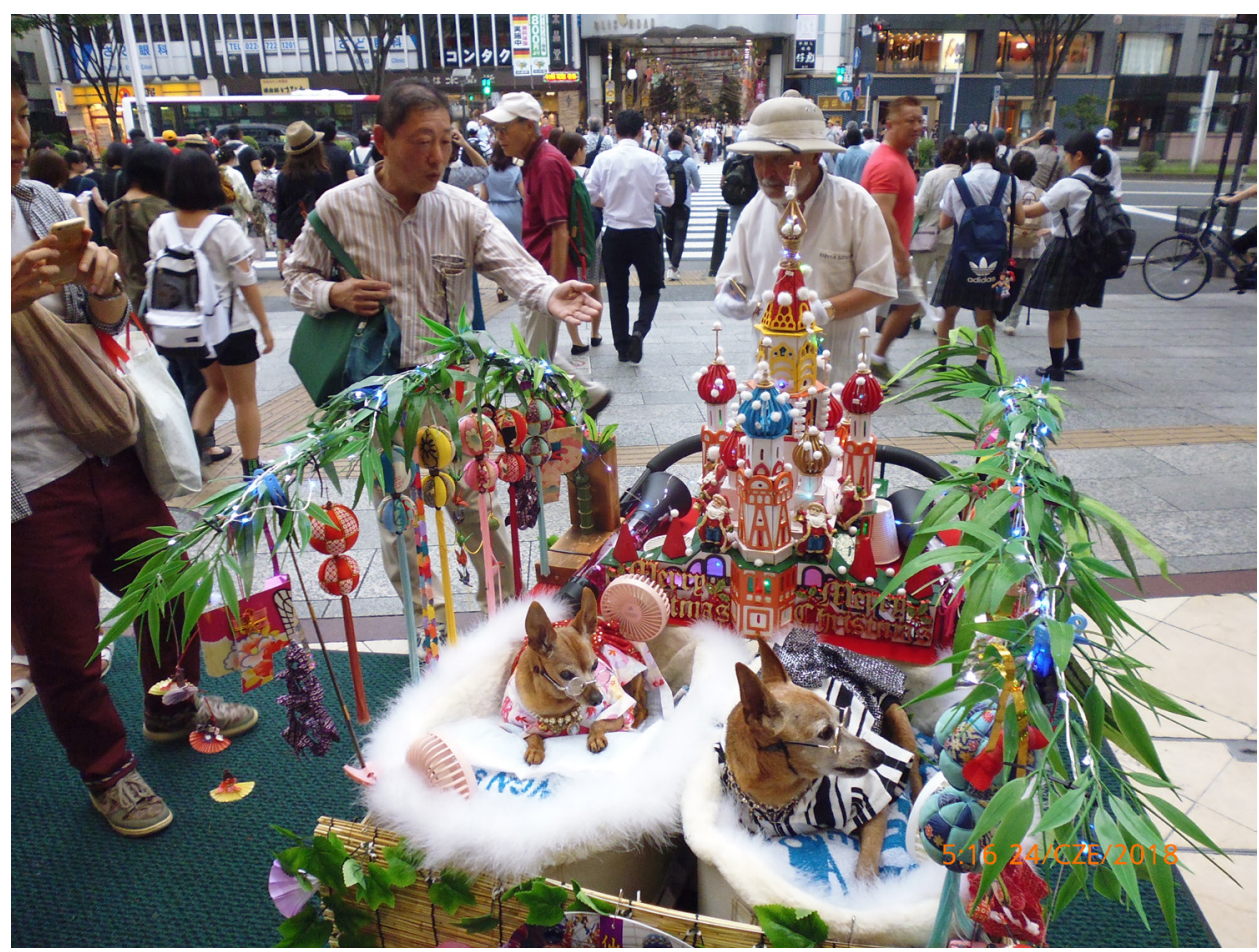

Fot. 13 Sendai, indywidualna wersja świętowania festiwalu Tanabata; lokalny dowcipniś posadził dwa ustrojone pieski na ruchomej platformie $z$ dziecięcego wózka oraz ozdobił ją gałązkami bambusa z zawieszonymi lampionikami, a z tyłu ustawił miniaturkę budowli przypominającej szopkę krakowską. Fot. W. Affelt

PS. Autor serdecznie dziękuje paniom Yukie Kumasaka i Mayumi Kikuchi za pomoc w organizacji pobytu w Matsushimie oraz Masumi Horino, kuratorowi Muzeum Świątyni Zuiganji, za udzielenie zgody na fotografowanie wnętrz świątyni i eksponatów muzealnych. 


\section{Bibliografia}

E. KAKIUCHI, Cultural heritage protection system in Japan: current issues and prospects for the future, National Graduate Institute for Policy Studies, 2014, p. 2, [online] http://www.grips.ac.jp/ r-center/wp-content/uploads/14-10.pdf (dostęp: 30.05.2019 r.)

\section{Strony internetowe}

Azuchi-Momoyama, [online]: https://pl.wikipedia.org/wiki/Azuchi-Momoyama (dostęp: 30.05.2019 r.)

"DATE Culture" fostered by Masamune, [online]: http://datebunka.jp/en/ (dostęp: 30.05 .2019 r.) Hideyoshi Toyotomi, [online] https://pl.wikipedia.org/wiki/Hideyoshi_Toyotomi (dostęp: 30.05.2019 r.)

Japan Heritage, podtytuł strony głównej, [online]: https://japan-heritage.bunka.go.jp/en/index. html (dostęp: 30.05.2019 r.)

Japan Heritage,[online] https://japan-heritage.bunka.go.jp/en/img/about/nihon_isan_ pamphlet_english.pdf (dostęp: 30.05 .2019 r.)

Japan Heritage Portal Site, [online] https://japan-heritage.bunka.go.jp/ja/special/sp190606.html (dostęp: 30.05.2019 r.)

Konwencja o ochronie dóbr kulturalnych w razie konfliktu zbrojnego wraz z regulaminem wykonawczym do tej konwencji oraz protokół o ochronie dóbr kulturalnych w razie konfliktu zbrojnego, podpisane w Hadze dnia 14 maja 1954 roku. [online] http://prawo.sejm.gov.pl/isap. nsf/DocDetails.xsp?id=WDU19570460212 (dostęp: 30.05.2019).

Konwencja UNESCO w sprawie ochrony niematerialnego dziedzictwa kulturowego, sporządzona w Paryżu dnia 17 października 2003 r. [online] http://prawo.sejm.gov.pl/isap.nsf/DocDetails. xsp?id=WDU20111721018

(dostęp: 30.05.2019).

Krajowa lista niematerialnego dziedzictwa kulturowego [online]

http://niematerialne.nid.pl/Dziedzictwo_niematerialne/Krajowa_inwentaryzacja/Krajowa_ lista_NDK/ (dostęp: 20.10.2019).

Law for the Protection of Cultural Property of May $30^{\text {th }} 1950$, [online]

https://en.unesco.org/sites/default/files/japan_law_protectionproperty_entno.pdf (dostęp: 30.05.2019).

Masamune Date, [online] https://pl.wikipedia.org/wiki/Masamune_Date (dostęp: 30.05 .2019 r.) Oshima Island, [w:] Google Map [online] https://www.google.com/ maps/@38.3644462,141.062592,58m/data=!3m1!1e3 (dostęp: 30.05.2019 r.)

Outline of "Japan Heritage" Program, Agency for Cultural Affairs, March 2015, para 1, [online] https://japan-heritage.bunka.go.jp/en/img/about/Outline\%20of\%20Japan\%20Heritage.pdf (dostęp: 30.05..2019 r.) 


\section{Waldemar J. Affelt}

Tanabata, [online] https://pl.wikipedia.org/wiki/Tanabata (dostęp: 30.05 .2019 r.)

Wojna boshin, [online] https://pl.wikipedia.org/wiki/Wojna_boshin (dostęp: 30.05.2019 r.) 